\title{
Genetic diversity of pituitary transcription factor 1 (PIT 1) gene in Nigerian local and exotic chicken
}

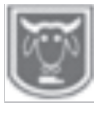

Abstract

Agaviezor, B. O. and Chukwuemeka, C. S.

Animal Science Department, University of Port Harcourt,

Port Harcourt, Nigeria

Corresponding author: brilliant.agaviezor@uniport.edu.ng

This study was carried out to investigate the genetic diversity of PIT1 gene in Nigerian local and exotic chicken breeds. Genomic DNA was extracted from the blood of Is a brown, Shika brown and Naked neck chickens which was used to amplify the PIT1 gene and later sequenced. Sequences were aligned and analyzed using Mega 6.0 and DNASp. The results revealed that Naked neck had 181 monomorphic sites and the least was observed in Isa brown (34). However, Is a brown had the highest number of polymorphic site (181) and the least was observed in Shika brown. Singleton variable sites also varied across breeds. Number of segregating sites was highest in Isa brown (174). The highest number of haplotypes was observed in Isa brown (11). Highest number of indel sites were observed in Isa brown (46) chickens. The highest estimates of average evolutionary divergence over sequence pairs within chicken breeds was observed in Isa brown (0.766) and the least in Shika brown (0.15). The highest genetic distance is between Isa brown and Naked neck and the least between Naked neck and Shika brown. The result obtained from this study revealed a clearer understanding of the genetic diversity in PIT1 gene across the different breeds. This information can be harnessed for better policies for conservation and breeding programs.

Keywords: Diversity, PIT1 gene, Nigeria, Chicken

\section{Introduction}

Over the past decade, different researches on different candidate genes and how they affect the performance of the Nigerian indigenous chicken have been carried out (Adebambo et al., 2009; Ajayi et al., 2013; Amusan et al., 2013; Agaviezor et al., 2018). Ajayi and Agaviezor (2012) explained major challenges of animal breeding and genetics in sustainable production in Agriculture and environment in Nigeria. Several researches have being done both at the phenotypic and molecular level to improvement of the Nigerian indigenous chicken. Adebambo et al. (2009) worked on the Mitochondrial DNA D-Loop analysis of South Western Nigerian Chicken. Also, Agaviezor et al. (2011) examined the correlation factor in body weight and laying performance while using the Nigerian local and some exotic chickens. Other improvement research on the Nigerian local chicken has been examined by Agaviezor et al. (2018) in their work on Single nucleotide polymorphism in growth hormone gene and its association with growth performance in chicken. The use of PIT 1 gene in genetic studies has been researched by some authors (Qinghua et al., 2008; Jin et al., 2018). Growth performance is a very significant part of economic trait in poultry production. This is controlled by a set of complex genes. PIT1 (growth hormone factor 1), also known as POU1F1, is a transcription factor for growth hormone that is responsible for pituitary development and hormone expression in mammals. This gene also regulates mammalian development. The expression of this gene and its association with growth parameters in chicken has been studied in some other chicken breeds but not in the Nigerian indigenous chickens. This study 


\section{Genetic diversity of pituitary transcription factor 1 (PIT 1) gene}

was therefore carried out for us to be able to assess the genetic diversity of Pituitary Transcription factor 1 (PIT 1) gene in Nigerian local and exotic chicken and to see how the information generated from this study will be used in the improvement of the growth traits of the Nigerian local chicken breeds.

\section{Materials and methods}

This research was carried out at the Poultry Unit of the Research and Teaching Farm of the Faculty of Agriculture, University of Port Harcourt, Port Harcourt. Thirty twenty-four (24) weeks old chickens comprising of 10 Shika brown, 10 Isa brown and 10 Naked neck chickens were randomly selected from a flock of about 100 chickens. Three (3) mLs of blood was collected from each bird from each bird from the wing vein in a $5 \mathrm{~mL}$ bottle gently mixed with the EDTA to prevent coagulation. The bottles were kept in an ice pack and transferred to the laboratory where they were preserved at $-4^{\circ} \mathrm{C}$ until DNA extraction.DNA was extracted from the blood of the chicken using Quick-DNA Miniprep Plus kit by Zymo Research, following the manufacturer's instruction. Polymerase Chain Reaction was done using the DNA and PIT1 primer. 2.5ul of 10x PCR buffer, 1.0 ul of $25 \mathrm{Mm} \mathrm{MgCl2}$, $1.0 \mathrm{ul}$ of 5 p M o 1 f o r w a r d p r m e r (GGACCCTCTCTAACAGCTCTC) and $1.0 \mathrm{ul}$ of $5 \mathrm{pMol}$ reverse primer (GGGAAGAATACA CAGGGAAAGG). Also to be added is $1.0 \mathrm{ul}$ DMSO, $2.0 \mathrm{ul}$ of 2.5Mm DNTPs, 0.1ul Taq 5u/ul, $3.0 \mathrm{ul}$ of 10ng/ul DNA and 13.4 ul water. A touch down PCR condition that involves initial denaturation at $94^{\circ} \mathrm{C}$ for 5 minutes, 9 Cycles of denaturation at $94^{\circ} \mathrm{C}$ for 15 seconds, annealing temperature at $62^{\circ} \mathrm{C}$ at 20 seconds and extension at $72^{\circ} \mathrm{C}$ for 30 secondswas carried out. This was followed by 35 cycles of denaturation at $94^{\circ} \mathrm{C}$ for 15 seconds, annealing temperature at $58^{\circ} \mathrm{C}$ for 20 seconds and extension at $72^{\circ} \mathrm{C}$ for 30 seconds and a final extension at $72^{\circ} \mathrm{C}$ for 7 minutes.PCR products of PIT 1 gene of the chickens were sent for sequencing at the International Institute for Tropical Agriculture (IITA), Ibadan, Nigeria. DNA sequences were aligned using Mega 6.0. Also, sequence variation parameters and genetic similarities and diversities were determined using Mega 6.0 and DNAsp Version 5.

\section{Results}

Table 1 shows the variation in polymorphic sites in PIT 1 gene across chicken breeds studied. The highest value of sites with alignment gaps was observed in Isa brown (133). This was followed by Naked neck (41) and the least was observed in Shika brown (16). The highest number of monomorphic sites was observed in Shika brown (246) and was followed by Naked neck with181 monomorphic sites and the least in Isa brown (34). However, Isa brown had the highest number of polymorphic site (181) and the least was observed in Shika brown. Singleton variable sites also varied across breeds. The highest value was observed in Naked neck (106) and was followed by Shika brown (66) and the least value was observed in Isa brown chickens (28). Parsimony informative sites were highest in Isa brown (153). No values of parsimony informative sites were observed for both Naked neck and Shika brown. The total number of sites analysed was highest in Shika brown (312). Naked neck had 287 sites and Isa brown, 215 sites. Theta-W per sequence highest value was observed in Isa brown (93.77). This was followed by Naked neck (78.67) and then Shika brown (46.00). For Theta - W per site, the highest value was observed in Isa brown (0.29) and the least was observed in Shika brown chickens (0.14). 


\section{Agaviezor and Chukwuemeka}

Variation in polymorphic sites in PIT 1 gene across chicken breeds studied have been reported by some authors. According to Tamura et al. (2013), gaps in sequences are often inserted during the alignment of homologous regions of sequences. These gaps represent deletions or insertions that are generally called indels. They introduce some complications in distance estimation. According to Blanquer-Maumont and Crouau-Roy (1995) in their work on polymorphism, monomorphism, and sequences in conserved microsatellites in primate species, they reported that dimeric short tandem repeats are one of the sources of highly polymorphic markers in mammals. They further stated that genetic variation in sequences at hypervariable loci are extensively used for linkage analysis. They can also be used for the identification of individual species and for assessing genetic diversity and relatedness among populations.

Table 1: Variation in polymorphic sites in PIT 1 gene across chicken breeds studied

\begin{tabular}{lrrr}
\hline Parameters & Isa brown & Naked neck & Shika brown \\
\hline Sites with alignment gaps & 113 & 41 & 16 \\
Monomorphic sites & 34 & 181 & 246 \\
Polymorphic sites & 181 & 106 & 66 \\
Singleton variable sites & 28 & 106 & 66 \\
Parsimony informative sites & 153 & 0 & 0 \\
Total number of sites & 215 & 287 & 312 \\
Theta - W per sequence & 93.76 & 46.00 & 78.66 \\
Theta - W, per site & 0.28 & 0.14 & 0.25 \\
\hline
\end{tabular}

Table 2 shows the variation in gene flow and genetic differentiation in PIT 1 gene in the chicken breeds studied. Number of segregating sites was highest in Isa brown (174). This was followed by Naked neck (62) and the least value was observed in Shika brown (41). For number of haplotypes, the highest value was observed in Isa brown (11). Naked neck and shika brown had the same number of haplotypes (3). Haplotype diversity did not vary across the three breeds of chickens (1.000). For nucleotide diversity, the highest value was observed in Isa brown (0.40). This was followed by Naked neck $(0.20)$ and the least in Shika brown (0.13).

Table 2: Gene flow and genetic differentiation in PIT 1 gene among chicken breeds

\begin{tabular}{llll}
\hline Parameters & Isa brown & Naked neck & Shika brown \\
\hline Number of segregating sites, S & 174 & 62 & 41 \\
Number of haplotypes, H & 11 & 3 & 3 \\
Haplotype diversity, H D & 1.000 & 1.000 & 1.000 \\
Nucleotide diversity, Pi & 0.40245 & 0.20192 & 0.13462 \\
Nucleotide diversity with J C, PIJC & 0.76676 & 0.24528 & 0.14913 \\
\hline
\end{tabular}

Table 3 shows the variation in insertion deletion polymorphism in PIT 1 gene in the three breeds of chicken studied. Total number of indel sites analyzed showed the highest value in Isa brown (46) chickens. This was followed by Naked neck (22) and then Shika brown with the least value (10).
Number of indel sites observed was highest in Isa brown (113). This was followed by naked neck (38) and the least value was observed in Shika brown (12). Total number of excluded over lapping indel sites had the highest value in Isa brown (67). Naked neck was next (38) and the least 


\section{Genetic diversity of pituitary transcription factor 1 (PIT 1) gene}

value was observed in Shika brown (2). More so, highest number of indel and nonindel sites were observed in Shika brown (322) followed by Naked neck (309) and Isa brown (261). For the total number of indels events analyzed, the highest value was recorded in Isa brown (41). Naked neck was next (19) and the least value was observed in Shika brown (10). For the total number of indels events, Isa brown had the highest value of 58. Naked neck had 21 and the least value was observed in Shika brown (13). Total number of excluded overlapping indel events was highest in Isa brown (17). This was followed by Shika brown (3) and the least value was recorded in Naked neck chickens (2). For average indel length event, the highest value was observed in Isa brown (1.32). Naked neck was next (1.16) and the least value was observed in Shika brown (1.0). Average indel length also

Table 3. Insertion Deletion Polymorphism

\begin{tabular}{l}
\hline Parameters \\
Total number of indel sites analyzed \\
Total number of indel sites \\
Total number of excluded over lapping indel sites \\
Total number of indels events analyzed I \\
Total number of indels events \\
Total number of excluded over lapping indel events \\
Average indel length event \\
Average indel length \\
Number of indel haplotypes \\
Indel Haplotype diversity \\
Indel diversity, K \\
Indel diversity per site Pi \\
Theta (per sequence form 1, Theta (1))
\end{tabular}

Figure 1 shows the estimates of average evolutionary divergence over sequence pairs within chicken breeds. Analyses were conducted using the Maximum Composite Likelihood model (Tamura et al., 2004). The analysis involved 17 nucleotide sequences. Codon positions included were $1 \mathrm{st}+2 \mathrm{nd}+3 \mathrm{rd}+$ Noncoding. All positions varied. Isa brown had the highest value (1.21) and was followed by naked neck (1.12) and the least value was observed in Shika brown (1.00). Number of indel haplotypes was highest in Isa brown (11). Naked neck and Shika brown chickens had the same value (3). For indel haplotype diversity, there was no differences across the three chicken breeds studied (Isa brown, Naked neck and Shika brown). Indel diversity was highest in Naked neck (12.67). This was followed by Isa brown (11.09) and the least value was observed in Shika brown (6.67). For indel diversity per site, Isa brown and Naked neck had same value (0.04) and the least value was observed in Shika brown (0.02). While considering Theta (per sequence from 1, Theta (1)), the highest value was observed in Isa brown (14.01) and was followed by Naked neck (12.67) and the least value was observed in Shika brown (6.67).

\begin{tabular}{lll} 
Isa brown & Naked neck & Shika brown \\
\hline 46 & 22 & 10 \\
113 & 38 & 12 \\
67 & 16 & 2 \\
261 & 309 & 322 \\
41 & 19 & 10 \\
58 & 21 & 13 \\
17 & 2 & 3 \\
1.317 & 1.158 & 1.00 \\
1.269 & 1.167 & 1.00 \\
11 & 3 & 3 \\
1.000 & 1.000 & 1.00 \\
11.091 & 12.667 & 6.667 \\
0.042 & 0.04099 & 0.02070 \\
13.998 & 12.667 & 6.667
\end{tabular}

containing gaps and missing data were eliminated. There were a total of 208 positions in the final dataset. Evolutionary analyses were conducted in MEGA6 (Tamura et al., 2013). The highest estimates of average evolutionary divergence over sequence pairs within chicken breeds was observed in Isa brown (0.766) and the least in Shika brown (0.15). 


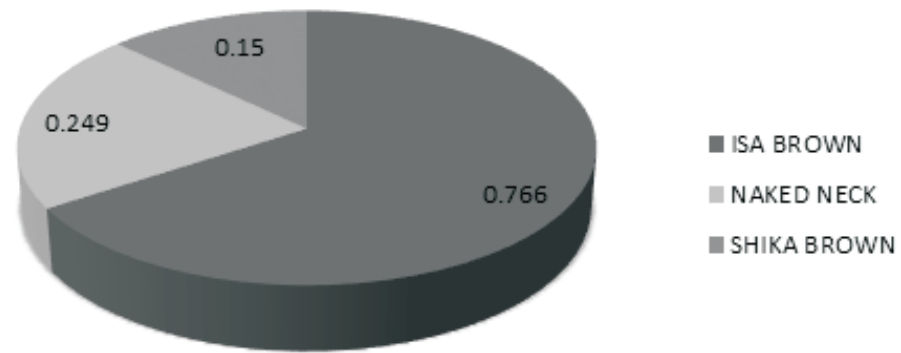

Figure 1: Estimates of Average Evolutionary Divergence over Sequence Pairs within chicken breeds

Table 4 revealed the genetic distance in PIT 1 gene between the three chicken breeds studied. The highest genetic distance is between Isa brown and Naked neck and the least between Naked neck and Shika brown. This result was expected because Isa brown is an exotic breed while Naked neck and Shika brown are breeds indigenous to Nigeria.

Table 4: Genetic distance in PIT 1 gene across the chicken breeds studied

\begin{tabular}{llll}
\hline Breeds & Isa Brown & Naked Neck & Shika brown \\
\hline Isa Brown & 0 & & \\
Naked Neck & 0.578 & 0 & 0 \\
Shika brown & 0.545 & 0.264 & 0 \\
\hline
\end{tabular}

\section{Discussion}

Variations in polymorphic sites were observed across the poultry breeds. These variations could be as a result of mutation and adaptation over the years. Gao et al. (2017) in their work on the genetic diversity of chicken breeds from Jiangxi, assessed the BCDO2 and the complete mitochondrial DNA D-Loop region and reported number of polymorphic sites as 31 and number of singleton variable sites as 3 . Pandey et al. (2002) also in their work on microsatellite analysis of three poultry breeds of India observed the parismony informative sites as 28 and total number of sites was observed in a range of 5-267. Variation in DNA polymorphism was observed across poultry breeds. These polymorphisms were observed in the average number of difference. This result is supported by Gao et al. (2017) who observed values ranging from 2.720-7.571 and also nucleotide diversity ranging from $0.00221-0.00615$. Also the variation in gene flow and genetic differentiation were observed across poultry species. These variations occurred as a result of series of changes undergone by the different poultry breeds over the years. These variations were found in areas such as number of segregating sites which was within the range of 16-35 which is in the range reported by Pandey et al. (2002). Also haplotype diversity was reported by Gao et al. (2017) to be within the range of 4-23 and the nucleotide diversity was found to be $2.87 \pm 0.28$ as reported by Mingming et al. (2008) in their work on the IGFIR gene and their genetic effects on chicken early growth and carcass traits. Furthermore, nucleotide 
diversity was observed to be 23 by Qinghua et al. (2008) in their work on PIT1 gene polymorphism were associated with chicken growth trait. The genetic distance between poultry breeds as observed by Pandey et al. (2002) was within the range of $0.5609-0.8982$. The result obtained from this study revealed a clearer understanding of the genetic diversity in PIT1 gene across the different breeds. This information can be harnessed for better policies for conservation and breeding programs.

\section{References}

Adebambo, A. O., Bjørnstad, G., Bulimo, W., Jianlin, H., Kierstein, G., Mazhani, L., Podisid, B., Hirbo, J., Agyemang, K., Wollny, C., Gondwe, T., Zeuh, V., Tadelle, D., Abebe, G., Abdoulaye, P., Pacoi, S., Serunjogi, L., Abrerrahman, M., Sow, R., Weigend, S., Sanfo, R., Gaye, F., Ssewanyana, E., Coulibalyk, M. D., Teme, B. and Hanotte, O. 2009. Mitochondrial DNA D-Loop analysis of South Western Nigerian Chicken, Arch. Zootec. 58 (224): 637-643.

Agaviezor, B. O., Ajayi, F. O., Gunn, H. H. and Adebambo, O. A. 2011. Nigerian indigenous vs exotic hens: the correlation factor in body weight and laying performance. African Research Review 5:(1)405-413.

Agaviezor, B. O., Ajayi, F. O. and Nwachukwu, C. C. 2018. Single nucleotide polymorphism in growth hormone gene and its association with growth performance in chicken, African Journal of Agriculture, Technology and Environment 7(2): 188 - 194

Ajayi, F. O. and Agaviezor, B. O. 2012. Challenges of animal breeding and genetics in sustainable production in Agriculture and environment; In: Challenges to sustainable production in agriculture and environment: Nigeria in perspective: (eds: H.M. Ijeomah and A.A. Aiyeloja, Topbase Nigeria Limited, Lagos, Nigeria (ISBN 978 - 978 - $933-048-5$ ), pp 184- 197 .

Ajayi, F. O., Agaviezor, B. O. and Wi hioka, S. N. ( (2 01013$)$. Haemoglobin genotypes in the Nigerian indigenous chicken in the Niger Delta region of Nigeria. International Journal of Advanced Biological Research, 3(1):13-16.

Amusan, S. A., Ikeobi, C. O. N., Adebambo, A. O., Agaviezor, B. O., Wheto, M., Durosaro, S. O., Adenaike, A. S., Ilori, B. M., Adedeji, T. A. and Adebambo, $O$. A. (2013). Effect of chicken genotype on growth performance and feed consumption in the development of broiler lines, Nigerian Journal of Animal Production 40(2):1-3.

Blanquer-Maumont, A. and CrouauRoy, B. 1995. Polymorphism, monomorphism, and sequences in conserved microsatellites in primate species. J. Mol. Evol. 41(4):492-7.

Gao, Y. S., Jia, X., Tany, X.J., Lu, J. X. and Huang, S. H. 2017. The genetic diversity of chicken breeds from Jiangxi, assessed with BCDO2 and the complete mitochondrial DNA D-loop region. Plos one 12(3): e0173192.

Jin, S., He, T., Tong, Y and Yang, L. 2018. Association of polymorphisms in PIT-1 gene with growth and feed efficiency in meat-type chickens. Asian Australasian Journal of Animal Sciences 31(11). 
Mingming, L., Xia, P., Min, Z., Chenglong, L., Qinghua, N., and Zhang, X. B. 2008. Polymorphism of the IGFIR gene and their genetic effects on chicken early growth and carcass traits. BMC genetics. 9(1). $\operatorname{Pg} 70$

Pandey, A. K., Tantia, M. S., Kumar, D., Mishra, B., Chaudhary, P. and Vish, R. K. 2002. Microsatellite analysis of three poultry breeds of India. Asian Australasian Journal of Animal Science. 15 (11):1536 1542.

Qinghua, N., Meixia, F., Liang, X., Min, Z., Zhangmin, L., Ziping, L., Guohuang, W., Wensen, B., Canjian, L., Wei, Z. and Xiquan, Z. 2008. The PIT1 gene polymorphism were associated with chicken growth trait. $B M C$ genetics 1. 9: 20 .
Tamura, K., Nei, M. and Kumar, S. 2004. Prospects for inferring very large phylogenies by using the neighborjoining method. Proceedings of the National Academy of Sciences (USA) 101:11030-11035.

Tamura, K., Stecher, G., Peterson, D., Filipski, A. and Kumar, S. 2013. MEGA6: Molecular Evolutionary Genetics Analysis version 6.0. Molecular Biology and Evolution30: 2725-2729.

Received: $10^{\text {th }}$ October, 2019 Accepted: $15^{\text {th }}$ January, 2020 